\title{
Bone microstructure and diagenesis of saurischian dinosaurs from the Upper Cretaceous (Neuquén Group), Argentina
}

\author{
Elena Previtera ${ }^{1}$ \\ ${ }^{1}$ Instituto Argentino de Nivología, Glaciología y Ciencias Ambientales (IANIGLA), CCT-CONICET-Mendoza, Avda. Ruiz Leal s/n \\ Parque General San Martín, C.C. 330, (5500), Mendoza, Argentina. \\ eprevitera@mendoza-conicet.gob.ar
}

\begin{abstract}
The Neuquén Basin in northwestern Patagonia, Argentina, holds the most important record of Cretaceous dinosaurs in South America.The Neuquén Group (Upper Cretaceous) is the richest dinosaur-bearing unit of the basin. It comprises the Río Limay, the Río Neuquén and the Río Colorado subgroups. In this study, dinosaur remains from the Río Neuquén and the Río Colorado subgroups outcropping in Mendoza are examined. In this group, isolated, disarticulated or partially articulated sauropods and theropods are abundant. However, little is known about the diagenetic history of fossil assemblages. In southern Mendoza, three fossiliferous sites were found in the areas of Paso de las Bardas (Quebrada Norte) and Cerro Guillermo (CG1, CG2). This study aims to add to the knowledge of diagenetic processes involving dinosaur remains from the Neuquén Group, as well as their relation to the depositional environment. Histologic features and diagenetic processes of dinosaur bones were analyzed through thin sections in order to interpret the degree of taphonomic alteration. The fossil-diagenetic processes inferred include substitution, fracturing, plastic deformation and different permineralization events. Combined analyses through X-ray diffractometry (XRD) and petrographic studies reveal the substitution of hydroxyapatite by francolite. The presence of fluorine -in one of the cases- suggests a link between the elemental composition and depositional environments: floodplain and fluvial channel. Permineralization stages include infilling of vascular canals, trabeculae and fractures with iron oxides and iron carbonate minerals during the burial history. This contribution represents an integral approach to the study of Cretaceous dinosaurs for assessing the diagenetic changes in the bone microstructure and the differential preservation of fossil remains in fluvial environments.
\end{abstract}

Keywords: Bone Diagenesis, Dinosaurs, Upper Cretaceous, Neuquén Group, Argentina.

RESUMEN. Microestructura ósea y diagénesis de dinosaurios saurisquios del Cretácico Superior (Grupo Neuquén), Argentina. La Cuenca Neuquina, en el noroeste de la Patagonia, Argentina, comprende el registro más importante de dinosaurios cretácicos en América del Sur. El Grupo Neuquén (Cretácico Superior) es la unidad portadora de dinosaurios más rica de la cuenca y está compuesto por los subgrupos Río Limay, Río Neuquén y Río Colorado. En este estudio, se examinan restos de dinosaurios de los subgrupos Río Neuquén y Río Colorado aflorantes en Mendoza. En este grupo, ejemplares de saurópodos y terópodos aislados, desarticulados o parcialmente articulados son abundantes. Sin embargo, se sabe poco acerca de la historia diagenética de estas asociaciones fósiles. En el sur de Mendoza, tres sitios fosilíferos se encontraron en las áreas de Paso de las Bardas (Quebrada Norte) y Cerro Guillermo (CG1, CG2). Este estudio tiene como objetivo mejorar el conocimiento de los procesos diagenéticos que involucran restos de dinosaurios del Grupo Neuquén, así como su relación con el ambiente de depositacional. Las características histológicas y los procesos diagenéticos de los huesos de dinosaurios se analizaron a través de secciones delgadas con el fin de interpretar el grado de alteración tafonómica. Los procesos fosildiagenéticos inferidos incluyen la sustitución, fracturación, deformación plástica y diferentes eventos de permineralización. El análisis combinado a través de difractometría de rayos X (DRX) y estudios petrográficos revelaron la sustitución de la hidroxiapatita por francolita. La presencia de flúor -en uno de los casos- sugiere la vinculación entre la composición elemental y los ambientes depositacionales: llanura de inundación y canal fluvial. Las etapas de permineralización incluyen el relleno de canales vasculares, trabéculas y fracturas con óxidos de hierro y carbonatos de hierro durante la historia de enterramiento. Esta contribución representa un enfoque integral para el estudio de los dinosaurios cretácicos para evaluar los cambios diagenéticos en la microestructura ósea y la preservación diferencial de los restos fósiles en ambientes fluviales. 


\section{Introduction}

The Neuquén Basin, located in the northwestern Patagonia, Argentina, bears the most important record of Cretaceous dinosaurs in South America. This record includes Argentinosaurus huinculensis, one of the largest sauropods currently known (Bonaparte and Coria, 1993); Amargasaurus cazuai, a peculiar sauropod with large spines (Salgado and Bonaparte, 1991); and the large theropod Giganotosaurus carolinii (Coria and Salgado, 1995), among others. In particular, most dinosaur species from Argentina have been found in Upper Cretaceous strata of the Neuquén Group, northern Patagonia. These findings comprise numerous sauropods and theropods and have significance from both systematic and phylogenetic viewpoints (e.g., Bonaparte, 1991; Novas, 1996; Novas, 1997; Novas and Puerta, 1997; Salgado et al., 1997; Powell, 2003; González Riga, 2003; Wilson, 2002; Calvo and González Riga, 2003; Calvo et al., 2004; Curry Rogers, 2005; Coria and Currie, 2006; Calvo et al., 2007; González Riga et al., 2008; González Riga et al., 2009). In southern Mendoza, sauropod remains are relatively abundant. Their record, includes an articulated distal caudal series of an indeterminate saltasaurid titanosaur (Wilson et al., 1999), the species Mendozasaurus neguyelap (González Riga, 2003), Malarguesaurus florenciae (González Riga et al., 2009), and the latest discovery, Notocolossus gonzalezparejasi (González Riga et al., 2016). In addition to sauropods, theropod bones of Aerosteon riocoloradensis (Sereno et al., 2008) were collected in the same area.

In contrast with the numerous systematic studies published, sedimentological and taphonomic analyses are relatively scarce (e.g., Garrido et al., 2001; Chiappe et al., 2004; González Riga and Astini, 2007) hindering comparisons with other paleontological sites.

This study is a bone histology and diagenetic analysis of Malarguesaurus florenciae (González Riga et al., 2009), and undetermined sauropod and theropod remains from Mendoza. In this context, the study of the microstructure makes it possible to discern whether the changes in the bone are of biological origin or generated during diagenesis.

\section{Geological setting}

The Neuquén Basin is perhaps the best-known sedimentary basin in Patagonia with abundant occurrences of terrestrial and marine fossils. This basin is located at the eastern side of the Andes in west-central Argentina between $32^{\circ}$ and $40^{\circ}$ latitude South (Fig. 1). It covers an area of over $120,000 \mathrm{~km}^{2}$ and comprises a nearly continuous record of up to 6,000 $\mathrm{m}$ of stratigraphic thickness from the Late Triassic to Early Cenozoic (Schwarz, 2012). This sedimentary record includes continental and marine siliciclastics, carbonates and evaporites accumulated under a variety of basin styles, including syn-rift, postrift/sag and foreland phases (Legarreta and Uliana, 1991; Howell et al., 2005). The triangular-shaped basin (Fig. 1) shows two main regions, the Andean thrust and fold belt to the west and the Neuquén embayment to the east and southeast (Schwarz, 2012).

The Neuquén Group (early Cenomanian-middle Campanian) constitutes a sequence of continental sediments deposited during the initial stage of foreland of the Neuquén Basin (Franzese et al., 2003). It is the richest dinosaur-bearing unit of the basin, being theropods, ornithopods and sauropods among the most common fossils (Leanza et al., 2004). This group comprises a thick continental succession $(\sim 1,300 \mathrm{~m})$ of sandstones, conglomerates, and claystones that represent alluvial fans, fluvial systems, and playalake environments (Leanza and Hugo, 2001). The Neuquén Group (Fig. 2) is divided into -from bottom to top- the Río Limay, the Río Neuquén, and the Río Colorado subgroups (Ramos, 1981). This group is overlaid through erosional unconformity by the Loncoche Fm. (late Campanian-early Maastrichtian), the lower unit of Malargüe Group (Andreis et al., 1974; Digregorio and Uliana, 1980; Legarreta et al., 1989). The Loncoche Fm. consists of fluvial, lacustrine, and marginal marine facies (tidal flats, deltas and sabkhas (Parras et al., 1996; González Riga, 1999; Parras et al., 2001) related to a marine ingression from the east that influenced centralnorthern Patagonia near the end of the Cretaceous (Casadío, 1994). The fossil record includes bivalves, gastropods and numerous vertebrate remains, e.g., Rajiformes indet.; Lepisosteidae indet.; Teleostei indet.; Percodei indet.; Dipnoi (cf. Metaceratodus sp.); Leptodactylidae indet.; Chelidae (cf. Prochelidella sp. and cf. Yaminuechelys sp.); Plesiosauria indet.; Theropoda indet. and Titanosauridae indet. (González Riga, 1999; Previtera, 2005; Previtera and González Riga, 2008; Previtera, 2013).

In southern Mendoza, in Paso de las Bardas and Cerro Guillermo study areas, the Río Limay 


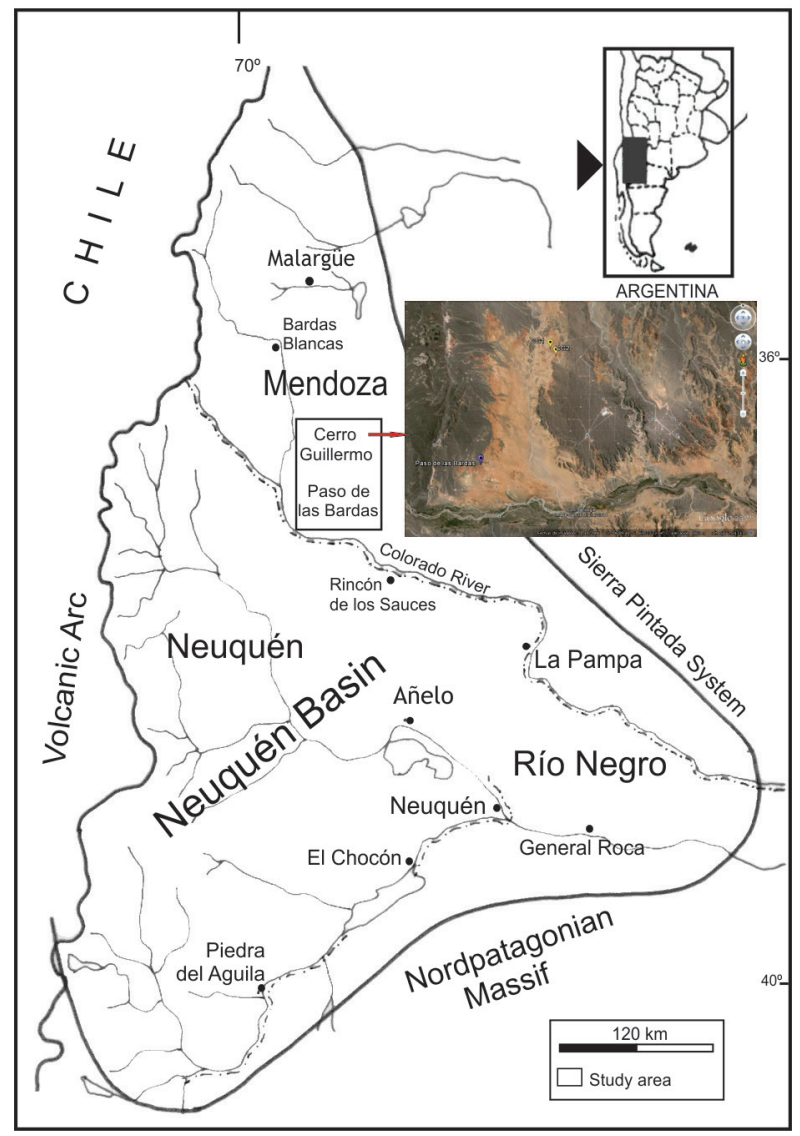

FIG. 1. Location map of the Neuquén Basin showing the Paso de las Bardas and Cerro Guillermo areas, Mendoza, Argentina.

Subgroup is the most ancient outcropping strata of the Neuquén Group. The silty-shaly unit in the Cerro Lisandro Fm. -on the top of the Río Limay Subgroupis covered by sandstones and shales from the Río Neuquén and Río Colorado subgroups (González Riga, 2002). These subgroups include sedimentary sequences composed of alluvial plains and channel complexes that periodically alternate, forming two distinct facies associations. In the Paso de las Bardas, the Portezuelo and Plottier formations -Río Neuquén Subgroup- are well exposed (González Riga et al., 2009). However, the outcrops situated northwards and eastwards of the Cerro Guillermo are correlated to the Bajo de la Carpa and Anacleto formations -Río Colorado Subgroup- (Previtera, 2011).

\subsection{Facies associations and paleoenvironments}

The architectural arrangement of the units in Paso de las Bardas and Cerro Guillermo shows multi-story sandstones bodies with fining-upward sequences and lateral accretion surfaces suggesting the presence of high sinuosity rivers -meandering systems- (Previtera, 2011). Especially in the Quebrada Norte site, Paso de las Bardas (González Riga et al., 2009, Fig. 2), architectural elements (sensu, Miall, 1996) were recognized representing different fluvial sub-environment, such as floodplain fines (FF); crevasse splay (CS); and crevasse channel (CR). These sequences (Table 1) are composed of a fine member mainly tabular, with greater thickness than the coarse member, dominated by overbank fines (Fm, Fl); crevasse splay (St, Sp, $\mathrm{Sh})$; and crevasse channel deposits (Sm, Sh, St, Sp) (Fig. 3A, B).

The Cerro Guillermo area comprises extensive outcrops of red pelitic facies interbedded with graybrown sandy fluvial channels. In this paper, the lithological features are described (Table 1).Two paleontological sites in Cerro Guillermo (CG1 and CG2, previously referred in Fig.1) are here analyzed. 


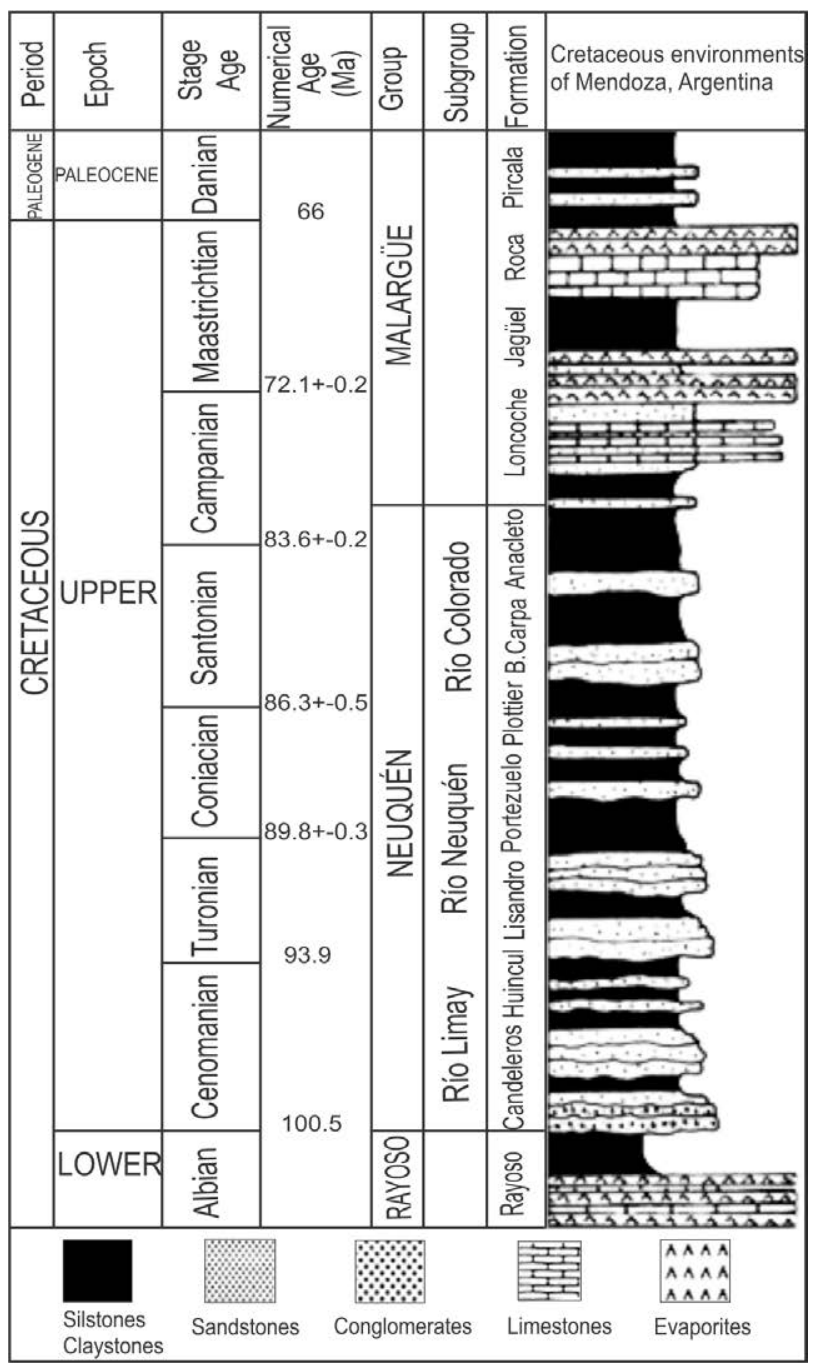

FIG. 2. Stratigraphic scheme of the lithostratigraphic units outcropping southern Mendoza, Argentina. Chronostratigraphic scale according to Cohen et al., 2013.

Both sites are composed of the following lithofacies (Fm, Fl, P, Sm, Sh, St, Sr, Sp) which represent the following architectural elements within the fluvial environment (Table 1); floodplain fines (FF) (Fig. 3C); crevasse splay (CS); crevasse channel (CR) and fluvial channel (CH) (Fig. 3D).

The fining-upward trend of the units analyzed is linked to a progression in the fluvial sub-environments, which starts with the deposition of channels and overbank deposits at the base of Portezuelo, Plottier and Bajo de la Carpa formations in Paso de las Bardas and Cerro Guillermo areas. These sections culminate in floodplain deposits with scarce lenticular sand channels and abundant sheet flood deposits on the top of the Portezuelo Formation in Paso de las Bardas (Previtera, 2011).

\section{Materials and Methods}

The study specimens consists of Malarguesaurus florenciae bones (IANIGLA-PV.110-8; IANIGLAPV.110-14) recovered in red massive claystones (Fm) of floodplain facies (Table 1) collected from the Quebrada Norte site, and sauropod bones (IANIGLA-PV.113-7; IANIGLA-PV.113-9) recovered in red sandy mudstones $(\mathrm{P})$ of floodplain deposits 
TABLE 1. LITHOFACIES AND ARCHITECTURAL ELEMENTS RECOGNIZED IN THE PASO DE LAS BARDAS AND CERRO GUILLERMO, MENDOZA, ARGENTINA.

\begin{tabular}{|c|c|c|c|c|c|c|}
\hline Cody & Lithology & Geometry & $\begin{array}{l}\text { Sedimentary } \\
\text { structures }\end{array}$ & Interpretation & $\begin{array}{l}\text { Architectural } \\
\text { elements }\end{array}$ & $\begin{array}{l}\text { Fluvial sub- } \\
\text { environments }\end{array}$ \\
\hline Fm & $\begin{array}{l}\text { Claystones } \\
\text { Siltstones }\end{array}$ & Tabular & Massive & $\begin{array}{l}\text { Deposits of } \\
\text { decantation, } \\
\text { overbank deposits }\end{array}$ & $\begin{array}{l}\text { Floodplain } \\
\text { fines (FF) }\end{array}$ & $\begin{array}{l}\text { Floodplain and } \\
\text { floodbasin deposits }\end{array}$ \\
\hline $\mathrm{Fl}$ & Siltstones & Tabular & $\begin{array}{l}\text { Fine horizontal } \\
\text { lamination }\end{array}$ & $\begin{array}{l}\text { Overbank deposits or } \\
\text { flood deposits }\end{array}$ & $\begin{array}{l}\text { Floodplain } \\
\text { fines }(\mathrm{FF})\end{array}$ & $\begin{array}{l}\text { Distal/proximal } \\
\text { floodplain deposits }\end{array}$ \\
\hline $\mathrm{P}$ & $\begin{array}{l}\text { Sandy/Mud } \\
\text { carbonates }\end{array}$ & $\begin{array}{l}\text { Fine } \\
\text { irregular } \\
\text { horizon }\end{array}$ & $\begin{array}{l}\text { Pedogenic } \\
\text { features: } \\
\text { concretions } \\
\text { and nodules }\end{array}$ & $\begin{array}{l}\text { Soil with chemical } \\
\text { precipitation }\end{array}$ & $\begin{array}{l}\text { Floodplain } \\
\text { fines }(\mathrm{FF})\end{array}$ & $\begin{array}{l}\text { Floodplain } \\
\text { (paleosols) }\end{array}$ \\
\hline $\mathrm{Sm}$ & $\begin{array}{l}\text { Fine to coarse } \\
\text { grained } \\
\text { sandstones }\end{array}$ & $\begin{array}{l}\text { Tabular to } \\
\text { lenticular }\end{array}$ & Massive & $\begin{array}{l}\text { Varied tractive } \\
\text { deposits intense } \\
\text { biological activity }\end{array}$ & $\begin{array}{l}\text { Crevasse } \\
\text { channel }(\mathrm{CR}) \\
\text { Channel }(\mathrm{CH})\end{array}$ & $\begin{array}{l}\text { Overflow deposits } \\
\text { (break in main } \\
\text { channel margin) } \\
\text { sandy fluvial } \\
\text { channels }\end{array}$ \\
\hline Sh & $\begin{array}{l}\text { Fine to } \\
\text { medium-grained } \\
\text { sandstones }\end{array}$ & $\begin{array}{l}\text { Tabular } \\
\text { lamination }\end{array}$ & $\begin{array}{l}\text { Horizontal } \\
\text { lamination }\end{array}$ & $\begin{array}{l}\text { Plane-bed deposits } \\
\text { (Critical flow) }\end{array}$ & $\begin{array}{l}\text { Crevasse splay } \\
\text { (CS) }\end{array}$ & $\begin{array}{l}\text { Overflow deposits } \\
\text { (delta-like } \\
\text { progradation from } \\
\text { crevasse channel } \\
\text { into floodplain) }\end{array}$ \\
\hline St & $\begin{array}{l}\text { Fine to coarse- } \\
\text { grained } \\
\text { sandstones }\end{array}$ & Lenticular & $\begin{array}{l}\text { Trough cross } \\
\text { stratification }\end{array}$ & $\begin{array}{l}\text { 3D bedforms (lower } \\
\text { Flow regimen) }\end{array}$ & $\begin{array}{l}\text { Crevasse } \\
(\mathrm{CS} / \mathrm{CR}) \\
\text { Channel }(\mathrm{CH})\end{array}$ & $\begin{array}{l}\text { Overflow deposits } \\
\text { channel belt } \\
\text { complexes }\end{array}$ \\
\hline $\mathrm{Sr}$ & $\begin{array}{l}\text { Fine to } \\
\text { medium-grained } \\
\text { sandstones }\end{array}$ & Tabular & $\begin{array}{l}\text { Ripple cross } \\
\text { lamination }\end{array}$ & $\begin{array}{l}\text { Ripple (lower flow } \\
\text { regime) }\end{array}$ & $\begin{array}{l}\text { Crevasse splay } \\
\text { (CS) }\end{array}$ & $\begin{array}{l}\text { Sheet-flood, distal } \\
\text { crevasse splay } \\
\text { deposits }\end{array}$ \\
\hline $\mathrm{Sp}$ & $\begin{array}{l}\text { Fine to coarse- } \\
\text { grained } \\
\text { sandstones }\end{array}$ & $\begin{array}{l}\text { Tabular to } \\
\text { lenticular }\end{array}$ & $\begin{array}{l}\text { Planar cross } \\
\text { lamination }\end{array}$ & $\begin{array}{l}\text { 2D bedforms (lower } \\
\text { Flow regime) }\end{array}$ & $\begin{array}{l}\text { Crevasse } \\
(\mathrm{CS} / \mathrm{CR}) \\
\text { Channel }(\mathrm{CH})\end{array}$ & $\begin{array}{l}\text { Overflow deposits } \\
\text { fluvial channel } \\
\text { complexes }\end{array}$ \\
\hline
\end{tabular}

(Table 1) from the CG1 site. Additionally, a long bone fragment of theropod (IANIGLA-PV.116-1) found in sandstones ( $\mathrm{Sp}, \mathrm{St})$ of fluvial channel complexes (Table 1) of the CG2 site is analyzed. These dinosaur remains are housed at the repository of the IANIGLA, Mendoza.

\subsection{Microscopic analysis}

Histologic features (Table 2) and diagenetic changes (Table 3 ) were studied through thin sections following the techniques outlined by Chinsamy and Raath (1992). The sections were observed under plane and cross-polarized light with a petrographic microscope BX 51-P Olympus. Histological terminology and definitions generally follow those of Francillon-Vieillot et al., 1990; Reid, 1996; Chinsamy-Turan, 2005. Petrographic analysis allowed determining taphonomic features as cracking, fracturing, deformation and permineralization. This paper takes the criteria used by various authors about the diagenetic classification (e.g., Schmidt and McDonald, 1979; Burley et al., 1985; Tucker, 1991; Scasso and Limarino, 1997; Holz and Schultz, 1998; Wings, 2004).

\subsection{X-ray diffractometry (XRD)}

Qualitative analysis of crystalline solids was performed with a PANalytical X'Pert PRO diffractometer using a copper lamp operated nickel filter at $40 \mathrm{kV}$, $40 \mathrm{~mA}$, scanning speed of $1^{\circ} / \mathrm{min}$., between $3^{\circ}$ and $60^{\circ}$ $2 \theta$, and eventually among $3^{\circ}$ y $40^{\circ} 2 \theta$, since the main reflections of oxides, hydroxides and sulphates of iron are in this range. For the preparation of the bone IANIGLA-PV.113-7 and the rock that surrounded the fossil, the samples were dried at room temperature, powderized ( $\sim 10$ grams) in an agate mortar and then introduced into the X-ray diffractometer PANalytical X'Pert PRO for approximately 2 hours. The analysis 

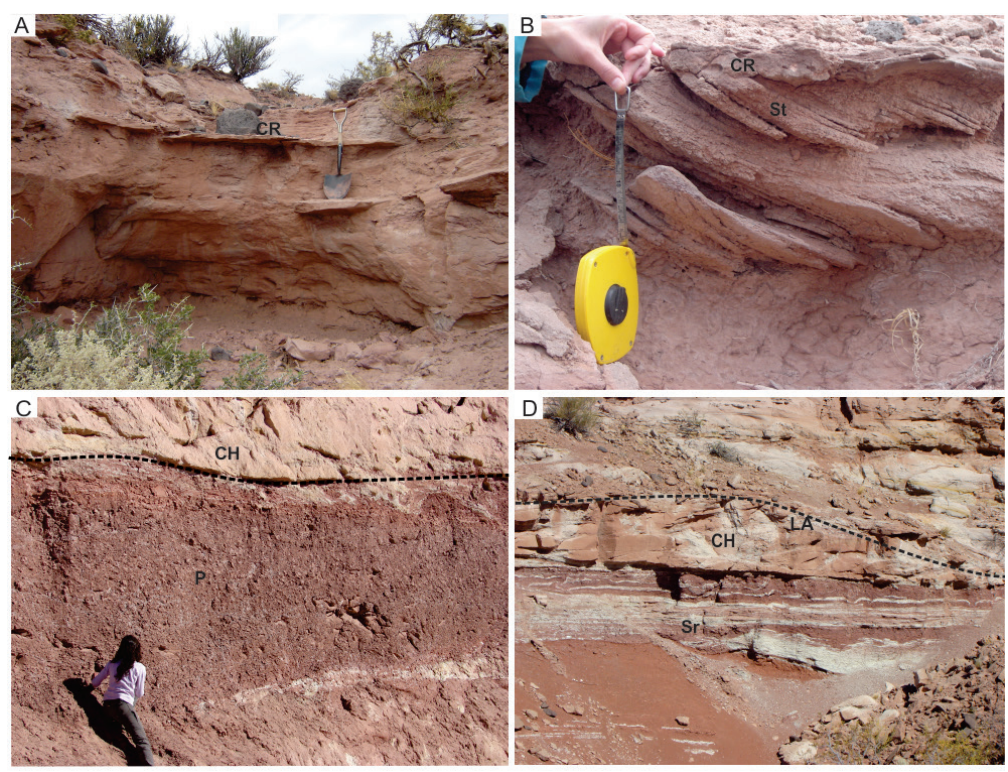

FIG. 3. Detail photographs of fluvial levels from Neuquén Group in the studied areas. A. Panoramic view of the overbank deposits in the Paso de las Bardas area; B. Detail of the crevasse channel with cross-bedded lenticular sandstones; C. Paleosol horizons underlying the channel belt in the Cerro Guillermo area; D. Channel belt complexes with lateral accretion surfaces interbedded with sandstones ripple cross-lamination in the Cerro Guillermo area.

TABLE 2. HISTOLOGICAL CHARACTERISTICS OF THE DINOSAURS SPECIMENS EXAMINED.

\begin{tabular}{|c|c|c|c|c|}
\hline Taxa & Specimen & Skeletal Element & Histological Characteristics & Growth Pattern \\
\hline \multirow[t]{2}{*}{$\begin{array}{l}\text { Malarguesaurus } \\
\text { florenciae }\end{array}$} & IANIGLA-PV 110.8 & Femur & $\begin{array}{l}\text { FLB; PO; SO; resorption cavity; } \\
\text { HT, with intense secondary } \\
\text { remodeling. Medullary zone } \\
\text { obliterated by fracturing and } \\
\text { cracking. }\end{array}$ & Cyclical fast growth. \\
\hline & IANIGLA-PV 110.14 & Appendicular Bone & $\begin{array}{l}\text { FLB, with simple canals PO; SO; } \\
\text { resorption cavity large cancellous } \\
\text { spaces and endosteal bony } \\
\text { trabeculae. }\end{array}$ & Cyclical fast growth. \\
\hline \multirow[t]{2}{*}{ Sauropoda } & IANIGLA-PV 113.7 & Femur & $\begin{array}{l}\text { FLB (plexiform pattern); PO; } \\
\text { SO; Haversian reconstruction; } \\
\text { cancellous spaces and endosteal } \\
\text { bony trabeculae. }\end{array}$ & $\begin{array}{l}\text { Sustained fast growth } \\
\text { sensitive to environments } \\
\text { fluctuations. }\end{array}$ \\
\hline & IANIGLA-PV 113.9 & Rib & $\begin{array}{l}\text { FLB; PO; SO, Haversian tissue; } \\
\text { resorption cavity; cancellous } \\
\text { spaces and endosteal bony } \\
\text { trabeculae. }\end{array}$ & $\begin{array}{l}\text { Cyclical growth sensitive } \\
\text { to environments } \\
\text { fluctuations. }\end{array}$ \\
\hline Theropoda & IANIGLA-PV 116.1 & Long Bone & $\begin{array}{l}\text { FLB; PO; longitudinal simple } \\
\text { canals; zones; annuli; LAGs; } \\
\text { SO; Haversian remodeling; } \\
\text { cancellous spaces and endosteal } \\
\text { bony trabeculae. }\end{array}$ & $\begin{array}{l}\text { Cyclical fast growth } \\
\text { indeterminate flexible } \\
\text { growth strategy. }\end{array}$ \\
\hline
\end{tabular}


TABLE 3. DIAGENETIC FEATURES OF THE DINOSAUR SPECIMENS EXAMINED.

\begin{tabular}{|c|c|c|c|c|c|}
\hline Taxa & Specimen & $\begin{array}{l}\text { Anatomical } \\
\text { identification }\end{array}$ & Facies & Diagenetic features & Diagenetic stages \\
\hline \multirow[t]{2}{*}{$\begin{array}{l}\text { Malarguesaurus } \\
\text { florenciae }\end{array}$} & IANIGLA-PV 110.8 & Femur & $\mathrm{FF}$ & $\begin{array}{l}\text { PO and VC mainly filled } \\
\text { by iron oxides and less } \\
\text { proportion of calcite. } \\
\text { Compaction and distortion. } \\
\text { Fractures cutting the VC. }\end{array}$ & $\begin{array}{l}\text { Fractures and vascular } \\
\text { canals filled by (1) silt } \\
\text { minerals; (2) iron oxides } \\
\text { cementation; ( } 3 \text { ) calcite } \\
\text { precipitation. }\end{array}$ \\
\hline & IANIGLA-PV 110.14 & $\begin{array}{l}\text { Appendicular } \\
\text { Bone }\end{array}$ & $\mathrm{FF}$ & $\begin{array}{l}\text { Fractures show a radial } \\
\text { pattern are associated with } \\
\text { mineral growth distorting } \\
\text { the structure of the VC. } \\
\text { Biological inclusions in the } \\
\text { cortical region. }\end{array}$ & $\begin{array}{l}\text { Permineralization events: } \\
\text { (1) growth of fibrous } \\
\text { calcite in VC wall; (2) iron } \\
\text { carbonates precipitation in } \\
\text { VC and fractures; ( } 3 \text { ) drusy } \\
\text { calcite cementation in VC } \\
\text { and CS. Outer calcareous } \\
\text { crusting favoring the } \\
\text { ingress of fibrous calcite in } \\
\text { the cortical wall. }\end{array}$ \\
\hline \multirow[t]{2}{*}{ Sauropoda } & IANIGLA-PV 113.7 & Femur & $\mathrm{FF}$ & $\begin{array}{l}\text { PO and VC mainly filled } \\
\text { by iron oxides and calcite. } \\
\text { Compaction and deforma- } \\
\text { tion in VC and SO. }\end{array}$ & $\begin{array}{l}\text { Diagenetic processes: } \\
\text { (1) initial iron oxides } \\
\text { cementation in VC; }(2) \\
\text { calcite precipitation in } \\
\text { fractures;VC and CS. }\end{array}$ \\
\hline & IANIGLA-PV 113.9 & Rib & $\mathrm{FF}$ & $\begin{array}{l}\text { Cortical region: SO and VC } \\
\text { filled by iron oxides and } \\
\text { calcite. Medullary cavity } \\
\text { with CS infilled by calcite } \\
\text { and ferro-dolomite. }\end{array}$ & $\begin{array}{l}\text { Diagenetic processes: (1) } \\
\text { fibrous calcite preci- } \\
\text { pitation; }(2) \text { ingress of } \\
\text { ferro-dolomite; }(3) \text { blocky } \\
\text { calcite cementation. }\end{array}$ \\
\hline Theropoda & IANIGLA-PV 116.1 & Long Bone & $\mathrm{CH}$ & $\begin{array}{l}\text { VC; SO and CS filled by } \\
\text { iron oxides; siderite and } \\
\text { calcite. Fracturing. }\end{array}$ & $\begin{array}{l}\text { VC, SO and CS filled by } \\
\text { three types of cements: (1) } \\
\text { iron oxides; (2) siderite } \\
\text { and (3) calcite precipita- } \\
\text { tion. Fractures cemented } \\
\text { in two events: (1) calcite } \\
\text { precipitation; (2) ingress of } \\
\text { semi-isotropic zeolite. }\end{array}$ \\
\hline
\end{tabular}

by X-ray diffractometry on the milled samples showed the presence of crystalline structures.

Institutional Abbreviations: IANIGLA-PV: Instituto Argentino de Nivología, Glaciología y Ciencias Ambientales, Mendoza, Argentina, Paleontología de Vertebrados.

Figures and Tables Abbreviations: A: annuli; C: cortex; Cal: calcite; CB: cancellous bone; CH: channel; CH: fluvial channel; CR: crevasse channel; CS: cancellous spaces; Dol: dolomite; FAp: fluorapatite; Fd: feldspar; Fe: iron; FF: floodplain fines; FLB: fibrolamellar bone; Fr: fracture; HT: Haversian tissue; I: illite; LA: lateral accretion;
LAGs: lines of arrested growth; M: medullary cavity; OHAp: hydroxyapatite; P: paleosol; Pl: plagioclase; PO: primary osteon; Qtz: quartz; S: silt; Sd: siderite; SO: secondary osteon; Sr: sandstones ripple cross-lamination; SR: secondary remodeling; St: sandstones cross-bedding; T: trabeculae; VC: vascular cannal; Z: zones; Zeol: zeolite.

\section{Pre-burial and Post-burial Modification}

The appendicular bones of Malarguesaurus florenciae recovered in a floodplain facies (IANIGLAPV.110-8; IANIGLA-PV.110-14) exhibit fractures 
assigned to pre-fossilization weathering. They display longitudinal cemented fractures parallel to bone fibers (stage 1 of Behrensmeyer, 1978) showing a low grade of pre-burial cracking. These fractures produced by pre-burial subaerial exposure and cemented during the post-burial stages. The bone remains show no evidence of abrasion, being thus assigned to the category 1 ("intact bone" of Alcalá, 1994). They are covered by an outer calcareous crust, likely inhibiting the influence of other alterative agents (e.g., abrasion).

The sauropod bones (IANIGLA-PV.113-7; IANIGLA-PV.113-9), also found in floodplain facies, show a high grade of pre-burial cracking and flaking (stages 1-3 of Behrensmeyer, 1978). Outermost concentric thin bone layers, of appendicular bones and ribs show flaking usually associated with splintered cracks. The appendicular bones display longitudinal cemented fractures parallel to bone fibers (stage 1 of Behrensmeyer, 1978) and some of them show transverse fractures. In some sectors, a deeper and more extensive flaking occurs until most of the outermost bone is gone. Thus, the inner cancellous bone of the epiphysis is exposed or absent (Smith, 1993). The weathered bones were more vulnerable to breakage and abrasion (Marshall, 1989). In this case, a moderate rounding of broken edges of bones (category 2 of Alcalá, 1994) was produced. The bones show no evidence of outer calcareous crusting (Previtera, 2011).

In contrast, the incomplete long bone found in a fluvial channel-lag (IANIGLA-PV.116-1) shows no evidence of pre-fossilization weathering as a result of subaerial exposure, predation or trampling. However, it displays intense processes of abrasion and selection by hydraulic transport. This bone exhibits cemented fractures perpendicular to the bone long axis occurred during fossil-diagenetic stages (Fernández López and Fernández Jalvo, 2002). Furthermore, post-fossilization weathering is evidenced by the presence of non-cemented fractures reflecting exhumation events (Previtera, 2011).

\section{Bone Mineralogy}

\subsection{Bone microstructure and diagenesis}

This section includes a detailed description of the histology features and the diagenetic changes of each specimen to indicate their preservation state
(Tables 2 and 3). The growth patterns of the minerals indicate relative time of formation

\subsubsection{Malarguesaurus florenciae (González Riga et al., 2009)}

Thin sections of a right femur (IANIGLA-PV. 110-8) show a thick cortex composed mostly of compact tissue with a high degree of secondary remodeling. The fibrolamellar bone is distributed into some interstices with primary osteons embedded in a woven bone matrix (Fig. 4A, Table 2). The perimedullary region shows a Haversian bone tissue with secondary osteons easily distinguishable by the presence of cementation lines (Fig. 4B). These osteons are the result of a process of secondary reconstruction, involving the removal of bone around a primary vascular canal, followed by subsequent redeposition of concentrically arranged lamellar bone in the erosion cavity (Chinsamy, 1997). The medullary region is obliterated due to the intense fracturing and cracking.

The cortical region of an incomplete appendicular bone (IANIGLA-PV. 110-14) is composed of fibrolamellar tissue containing simple canals and primary osteons. Toward the inner cortex, the perimedullary region contains abundant secondary osteons and resorption cavities (Fig. 4C). The medullary cavity shows large cancellous spaces and endosteal bony trabeculae (Fig. 4D).

The microstructure analysis of the Malarguesaurus shows two types of preservation (Table 3 ). In the femur, the original tissue is well preserved with vascular canals and primary osteons mainly filled by iron oxides and calcite. However, the bone tissue shows compaction and late-diagenesis distortion (Fig. 4E). Permineralization stages include: (1) an initial ingress of silt minerals in vascular canals and fractures, then (2) iron oxide infiltration and followed by $(3)$ calcite $\left(\mathrm{CaCO}_{3}\right)$ precipitation in the remaining pore space (Fig. 4F).

In the appendicular bone, the original microstructure is distorted by compaction and mineral growth. Abundant fractures associated with mineral growth distorting the structure of the vascular canals are observed. Permineralization events include: (1) an initial growth of isopachous fibrous calcite in vascular canal walls followed by (2) precipitation of iron carbonates (e.g., siderite) in vascular canals and fractures, and finally (3) deposition of drusy calcite cementation in vascular canals and cancellous spaces (Fig. 4G). 
The presence of siderite $\left(\mathrm{FeCO}_{3}\right)$ is confirmed by the dark brown crystals, rhombohedrons in clusters, and of typical globular structure. The bone has an outer calcareous crusting that suffered dissolution in some sectors favoring fibrous calcite cementation in the cortical wall (Fig. 4H). Near the cortex, tunnel-like biological inclusions are observed, likely caused by microorganisms (bacteria and/or fungi) involved in post-mortem bone destruction (Lyman, 1994) (dashed lines in Fig. 4I). The thin section shows the tunnels oriented longitudinally, parallel to the osteonal canals. This microbial alteration is manifested as circular or oval destructive foci surrounded by a relatively dense mineralized wall (Trueman et al., 2004).

\subsubsection{Sauropoda gen. et sp. indet.}

The diaphysis section of the femur (IANIGLA-PV. 113-7) shows a compact cortex surrounding a central cancellous region. Fibrolamellar bone contains primary osteons arranged in a plexiform pattern due to the presence of radial canals (Fig. 5A, Table 2). Haversian dense reconstruction is recognized by well-developed secondary osteons (Sander, 2000) growing above the primary structure (Fig. 5B). Medullary cavity shows large cancellous spaces and an intricate network of thin bony trabeculae forming islets (Fig. 5C).

The thin section of the dorsal rib (IANIGLA-PV. 113-9) has a cortical region composed of fibrolamellar tissue with primary osteons embedded in a woven bone matrix surrounding a central medullary cavity (Fig. 5D, Table 2). In the inner cortex, the perimedullary region displays resorption cavities infilled by centripetally deposited lamellar bone and secondary osteons (Fig. 5D). The medullary zone shows cancellous spaces and bony trabeculae. In this region, several layers of circumferential endosteal lamellar tissue are deposited along the boundaries of the erosion cavities (Fig. 5E).
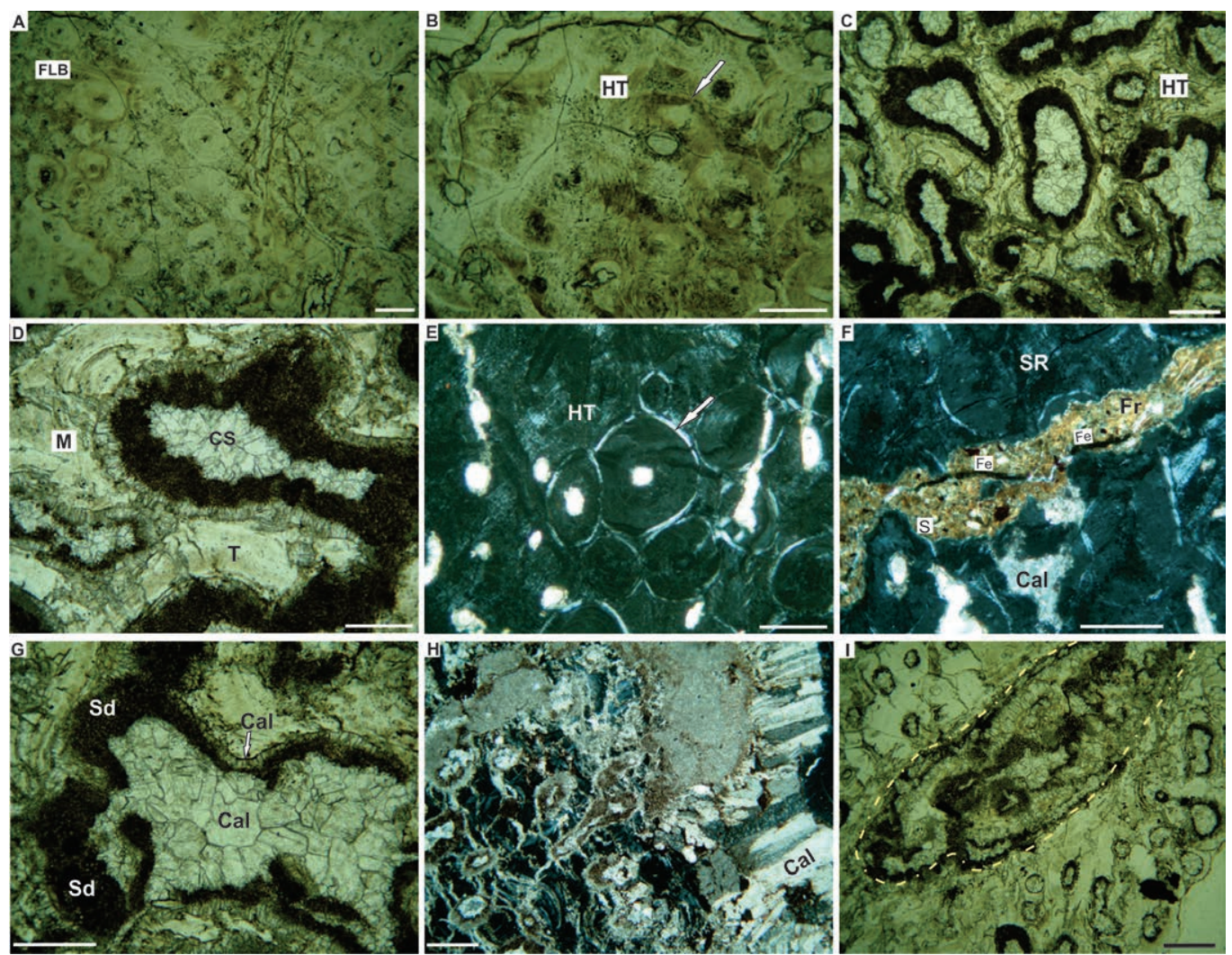

FIG. 4. Thin sections of Malarguesaurus florenciae. A, B, E, F: Femur IANIGLA-PV 110.8; C, D, G, H, I: Appendicular bone IANIGLA-PV 110.14. Photomicrographs in cross-polarized and plane-polarized light. Scale bar equals $1 \mathrm{~mm}$. See text for further explanation. 

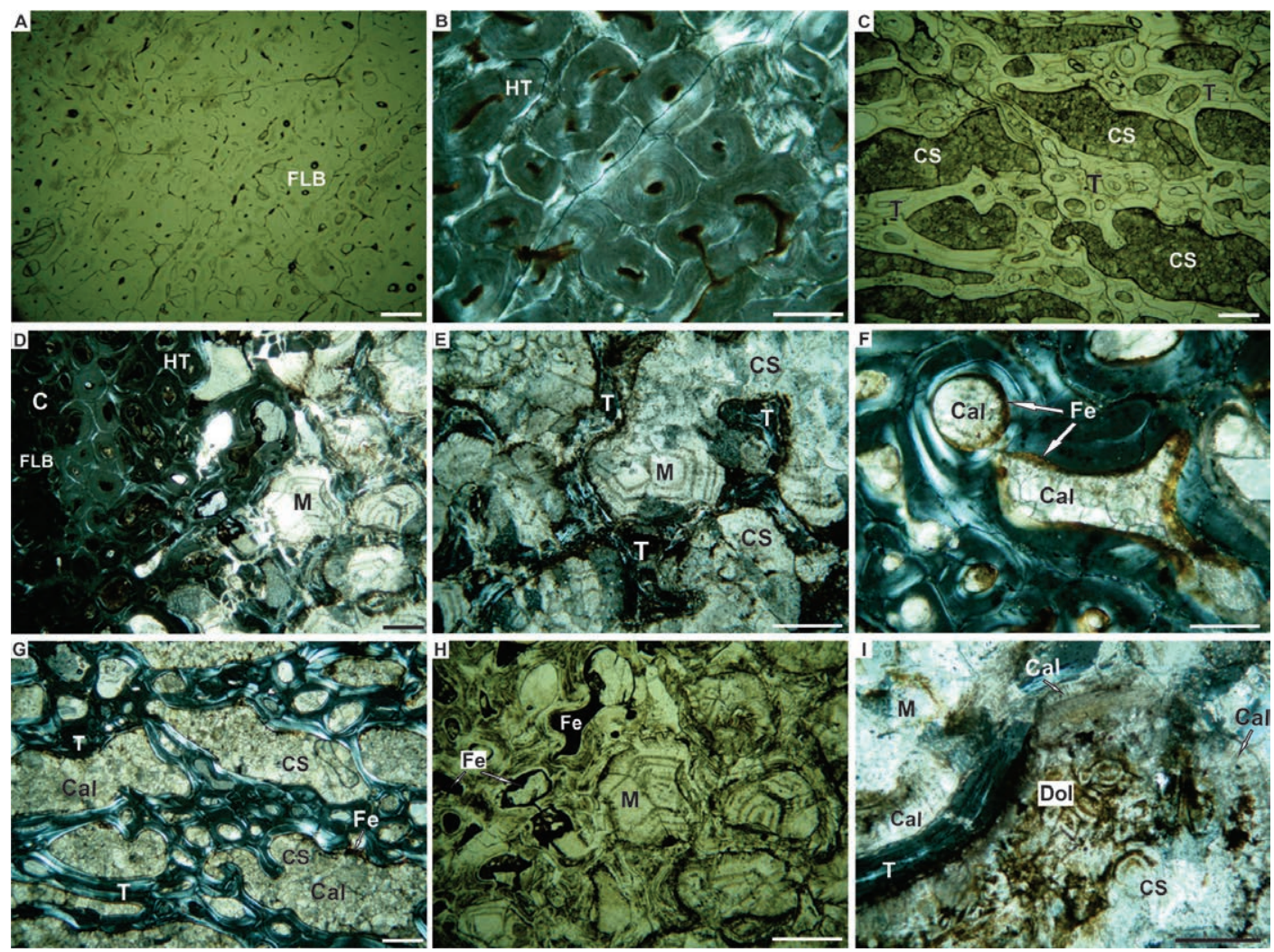

FIG. 5. Thin sections of Sauropoda indet. A, B, C, F, G: Femur IANIGLA-PV 113.7; D, E, H, I: Rib IANIGLA-PV 113.9. Photomicrographs in cross-polarized and plane-polarized light. Scale bar equals $1 \mathrm{~mm}$. See text for further explanation.

The microstructure of the femur reveals that the main diagenetic processes affecting the bones were permineralization, compaction and deformation (Fig. 5F, G, Table 3 ). The primary and secondary osteons are mainly filled by an initial precipitation of iron oxides followed by calcite cementation (Fig. 5F). The medullary region displays the same infill sequence of iron oxides and calcite in trabeculae and cancellous spaces (Fig. 5G).

The rib microstructure displays different episodes of mineralization (Fig. 5H, I, Table 3). The cortical region shows secondary osteons and vascular canals filled by iron oxides and calcite (Fig. 5H). The medullary cavity contains trabeculae and cancellous spaces infilled by calcite and dolomite with high iron content likely "ferro-dolomite" $\left[\mathrm{CaFe}\left(\mathrm{CO}_{3}\right)_{2}\right]$. According to the optical criterion, ferro-dolomite content is confirmed by the presence of rhomboid crystals (Scasso and Limarino, 1997). Figure 5I shows cancellous spaces with the following cementation events: (1) an initial isopachous fibrous calcite precipitation, then (2) ingress of rhombohedral ferro-dolomite and finally (3) blocky calcite cementation.

\subsubsection{Theropoda gen. et sp. indet.}

The thin section of the incomplete long bone (IANIGLA-PV. 116-1) shows compact cortex surrounding a central cancellous region. The cortical region is composed of fibrolamellar bone tissue. It contains longitudinally-oriented simple canals and primary osteons (Fig. 6A, Table 2). The rate of bone deposition is cyclical and is termed "zonal bone", and the resulting growth marks are the zones and annuli. Lines of arrested growth (LAGs) are present in the outer and mid-cortical region (arrows in Fig. 6B). Toward the inner cortex, the perimedullary region is dominated by secondary osteons resulting from a process of Haversian reconstruction (Fig. 6C-E). Inwards, a zone of coarse cancellous bone is observed. The medullary cavity shows large cancellous spaces and endosteal bony trabeculae (Fig. 6F). 
The well-preserved bone microstructure shows secondary osteons and vascular canals cemented by (1) iron oxides and then (2) calcite (Fig. 6C-E, Table 3). Some sectors of the sample exhibit vascular canals; secondary osteons and cancellous spaces filled by two types of cement: (1) first siderite and then (2) calcite (Fig. 6F, G). In the perimedullary region, an important fracture reveals episodes of cementation by: (1) first calcite and then (2) semi-isotropic zeolite (Fig. 6H). The bone displays cracking and non-cemented fractures superimposed onto secondary osteons showing a pattern of iron oxide alteration in the rim (Fig. 6I).

\subsection{X-Ray diffraction and petrographic analyses}

\subsubsection{Sauropoda gen. et sp. indet.}

The study material corresponds to a femoral fragment (IANIGLA-PV. 113-7) recovered in red sandy mudstones of floodplain deposits in the CG1 site. The diagenetic processes affecting the bone were permineralization -previously mentioned- and the substitution of hydroxyapatite by fluorapatite. $\mathrm{X}$-ray diffraction analysis showed crystalline phases (Fig. 7A). In the diffractogram, the fluorapatite is shown as the main signal identified by the following reflexions $\AA(25.8 \theta ; 31.9 \theta ; 33.1 \theta ; 34.1 \theta ; 40.0 \theta$; $46.9 \theta ; 49.5 \theta ; 50.7 \theta ; 53.1 \theta)$. Hydroxyapatite is observed in a smaller proportion. It is inferred from its characteristic reflexions $\AA(22.9 \theta ; 38.3 \theta ; 41.1 \theta$; $43.8 \theta ; 52.3 \theta ; 57.4 \theta)$. This analysis confirms the replacement of hydroxyapatite $\left[\mathrm{Ca}_{5}\left(\mathrm{PO}_{4}\right)_{33}(\mathrm{OH})\right]$ by francolite $\left[\mathrm{Ca}_{5}\left(\mathrm{PO}_{4}, \mathrm{CO}_{3}\right)_{3}(\mathrm{~F})\right]$, a carbonate-rich type of fluorapatite. The ionic substitution of hydroxyl $(\mathrm{OH})$ of the original hydroxyapatite by fluoride (F), results in fluorapatite. This is a typical mineral replacement of fossilized bone (Lucas and Prévôt, 1991; Elorza et al., 1999), and it has been described in other skeletal remains of Cretaceous dinosaurs (e.g., Paik et al., 2001; Rogers et al., 2010).
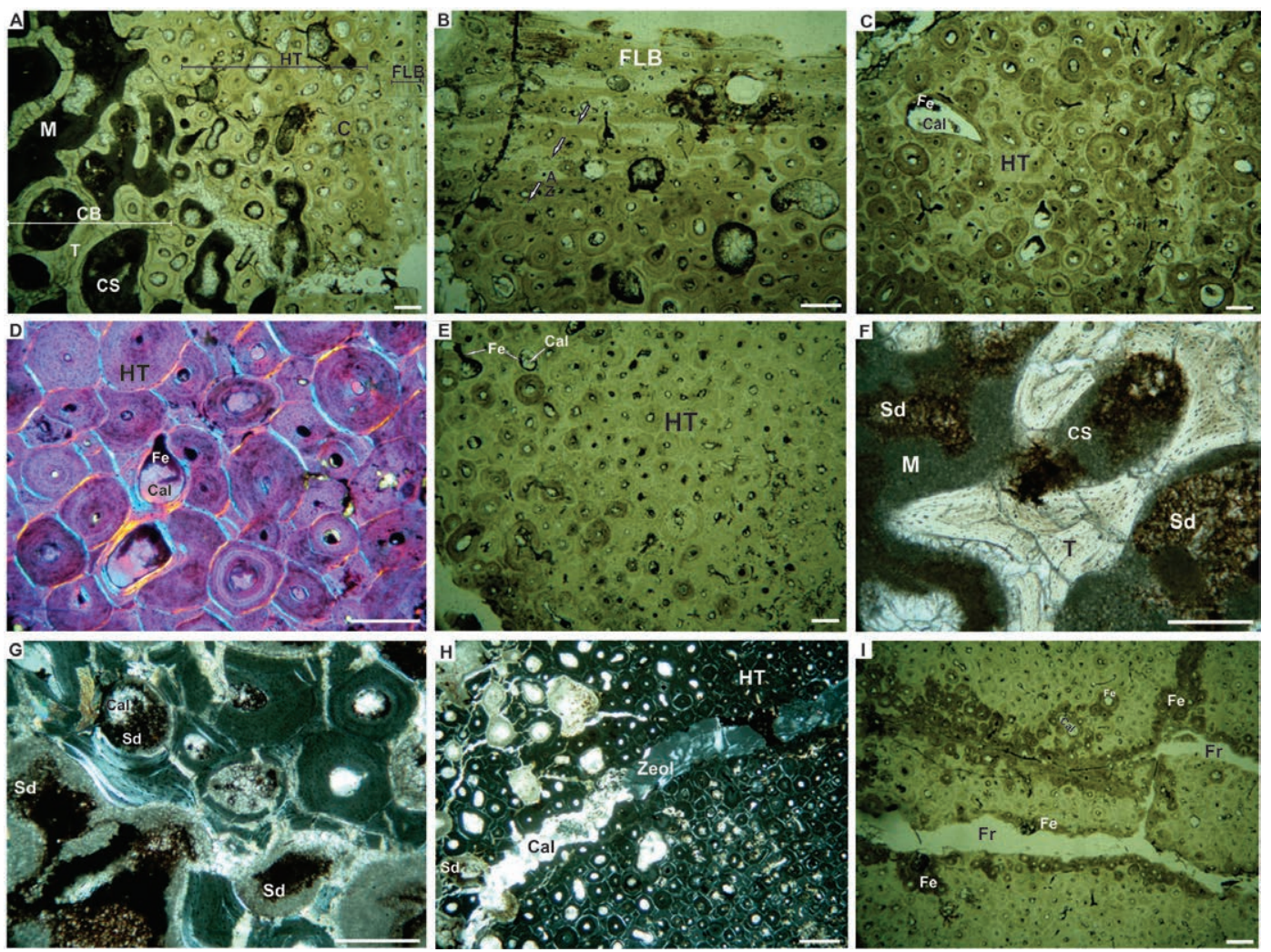

FIG. 6. Thin sections of Theropoda indet. A-I: Appendicular bone IANIGLA-PV 116.1. Photomicrographs in cross-polarized, planepolarized light and photo (D) with lambda wave plate. Scale bar equals $1 \mathrm{~mm}$. See text for further explanation. 


\subsubsection{Host Rock}

The analyzed sample consists of the sandy mudstone that was found surrounding the femur previously described. XRD revealed the presence of quartz, calcite, plagioclase, illite and potassium feldspar as the main phases in the diffractogram (Fig. 7B). The quartz is distinguished by its characteristic reflections $\AA(20.8 \theta, 26.6 \theta)$. In this analysis, muscovite and iron minerals were not observed. However, they were recognized through petrographic sections. The cross section (Fig. 7C) shows the mineral composition composed of a granular fraction where the main minerals are quartz (75\%) and feldspar (25\%). Muscovite appears as the secondary mineral. In the sample, silty-clay matrix $(\leq 50 \%)$ is observed, as well as a blocky calcite cement covering several grains of sediment (poikilotropic cement) or microcrystalline (ferrous carbonate) in more permeable sectors of the rock. In some sectors, cracks and burrows filled with drusy calcite cement and mottled iron oxides
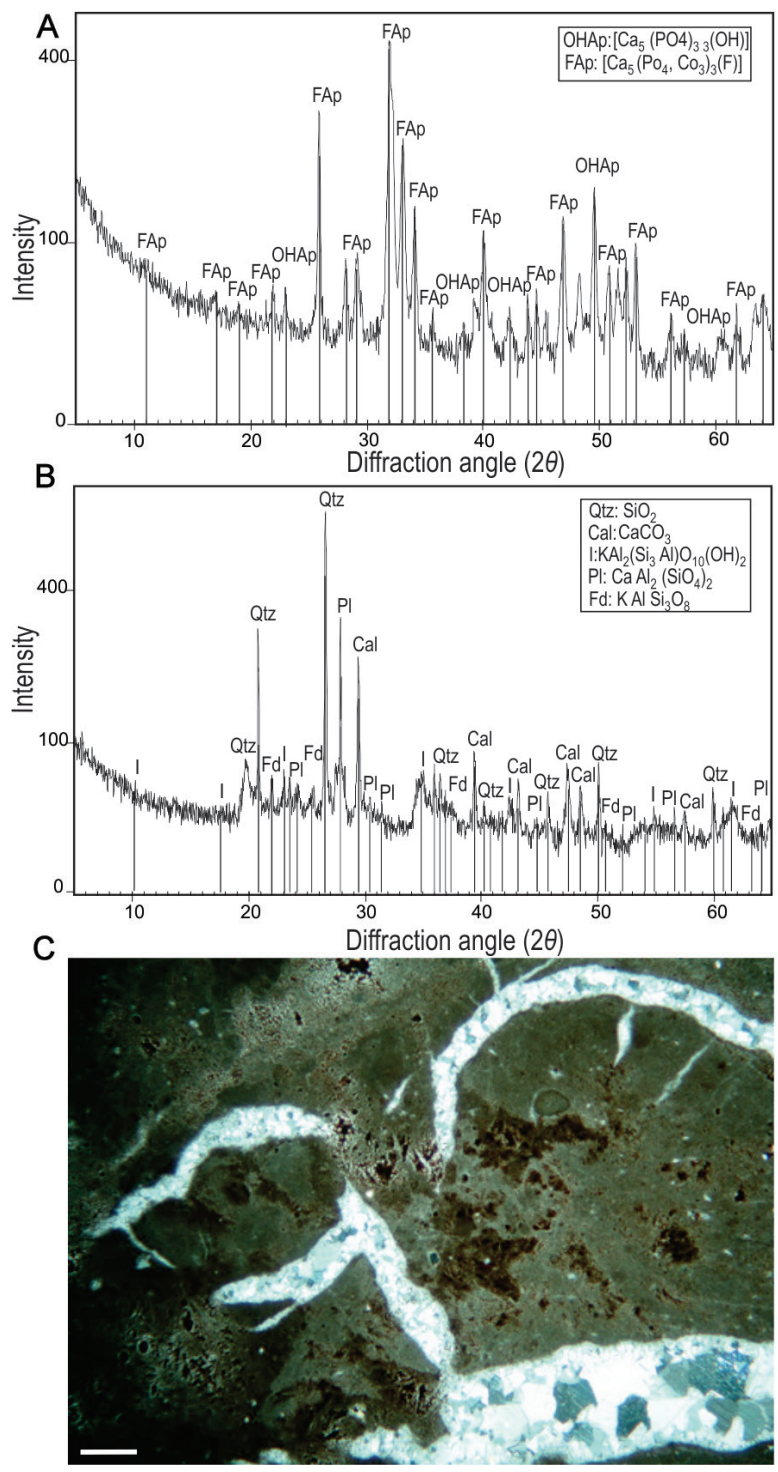

FIG. 7. X-ray diffraction and petrographic analyses. A: Femur fragment (IANIGLA- PV 113.7) indicating the predominance of fluor apatite over the hydroxyapatite; B: Sandy mudstone showing its main mineral phases; C: Photomicrograph of the host rock in cross-polarized light. Scale bar equals $1 \mathrm{~mm}$. 
can be observed.This latter is a consequence of the differential growth of carbonates within the calcic soil (paleosols level).

\section{Discussion}

\subsection{Histological implications}

The histological examination of dinosaurssauropods and theropods- reveals similar bone microstructure and growth patterns (as summarized in Table 2). The cortical zone of the all bones displays a preponderant well-vascularized fibrolamellar tissue indicating a high rate of bony deposition (Amprino, 1947; Chinsamy, 1993; Curry, 1999). The highly vascularized fibrolamellar tissue of the sauropod specimens can be assigned to the ontogenetic stage HOS-9 (Klein and Sander, 2008). The HOS-9 stage occurs in animals of up to $75 \%$ of adult size and it is coincident with the juvenile stages of Apatosaurus proposed by Curry (1999). Particularly, in the theropod bone, discontinuities in growth are noted, either interrupted or sustained, evidenced by the presence of annuli and LAGs indicating periodic arrests in growth. Despite the inferred rapid growth, bone deposition appears to have ceased occasionally as evidenced by arrest lines observed within the tissue. Similar features have been elsewhere reported in theropods (e.g., Madsen, 1976; Chinsamy, 1990; Varricchio, 1993).

The abundance of fibrolamellar cortical tissue and absence of EFS (External Fundamental System) in the sauropod specimens indicates that they were still growing at the moment of death (Klein and Sander, 2008). On the other hand, the existence of discontinuities in the theropod bone suggests changes in the growth rate. Likely, the lines of arrested growth reflect physiological stress due to environmental perturbations. According to Varricchio (1993), these lines suggest a growth cessation associated to a seasonal/annual environmental change. Starck and Chinsamy (2002) have suggested that LAGs are an expression of a high degree of developmental plasticity, which is the capability to respond to changes in the environment by evoking different developmental regimes (Smith-Gill, 1983). According to this study, the development of LAGs as a response to unfavourable environmental conditions, could be attributed to either the tectonic activity or to the relatively arid conditions during the deposition of
Neuquén Group (Martinsen et al., 1999; González Riga, 2002).

As mentioned above, fibrolamellar bone is considered characteristic of a rapid osteogenesis (de Buffrénil, 1980; Reid, 1990; Chinsamy, 1997), which in turn suggests an overall fast bone growth rate (de Ricqlès, 1972). This tissue has been reported in other extinct vertebrates like birds; pterosaurs; some pseudosuchians; basal archosauromorphs; captorhinids and pelycosaurs (de Ricqlès, 1976; Curry, 1999; Horner et al., 1999; de Ricqlès et al., 2003; Botha-Brink and Smith, 2011). Similar histological features of dinosaur bones analyzed here have been observed in other dinosaurs from Patagonia (e.g., Apesteguía, 2004; González Riga and Curry Rogers, 2006; Gallina, 2012; Ibiricu et al., 2013, among others).

\subsection{Taphonomic pathways}

Precipitation and mineral replacement are two of the complex diagenetic processes, which occur during infilling of openings in the bones (Downing and Park, 1998; Williams and Marlow, 1987; Pate et al., 1989; Piepenbrink, 1989; Wings, 2004). The dinosaur bones analyzed here show similar processes of mineralization and compaction (as summarized in table 3). However, slight differences in the types of cements precipitated and in the number of diagenetic events that occurred in the burial environments (floodplain and fluvial channel) have been recognized.

Prior to burial, the sauropod bones deposited in the floodplain likely underwent the following processes of pre-fossilization weathering: temperature changes, solar radiation, saturation and desiccation, all common in environments with episodic sedimentation (Bridge, 2003). Behrensmeyer (1978) described similar features in bones under arid or saline conditions. In the case here described, the presence of eolian sandstones at the Cerro Colorado section -Río Neuquén Subgroup- (González Riga, 2002) laterally correlated to the Malarguesaurus site suggests the development of sub-arid episodes within the floodplain deposits (González Riga et al., 2009).

After the burial, these bones experienced plastic deformation, a series of permineralization stages, and substitution. During early stages of diagenesis, voids and fractures were cemented by iron oxides (e.g., hematite), after which precipitation of iron carbonates (e.g., siderite), calcite and calcium iron carbonates 
(e.g., ferro-dolomite) took place. The Fe is likely present as hematite in the superficial part of the soil. The calcite occurred at deeper levels in the soil and shows a radial growth pattern and iron enrichment. This indicates local reducing conditions under the water table during precipitation, as it is described in previous research (Behrensmeyer et al., 1995; Retallack, 2001; Clarke, 2004). Calcite is present in almost all samples, indicating its importance as a void filler. Calcite appears to have been precipitated during the later stages of diagenesis, as suggested by Flügel (1982). This main cement occurs in both spongy and compact bone and it is represented by at least two generations: fibrous calcite cementation and blocky calcite generation (Previtera et al., 2016). The siderite often found in bedded sedimentary deposits with a biological component suggests a biogenic origin under low-oxygen and low-Ph conditions (Lim et al., 2004). Siderite perhaps indicates a special microbial influence in these bones (Mortimer et al., 1997). Furthermore, the presence of tunnel-like biological inclusions in appendicular bones, probably caused by microorganisms (bacteria/or fungi), could be attributed to the early stages of post-mortem bone decomposition. Bone decay microorganisms leave evidence creating tunnels or surface with partial erosion visible in thin sections. In all cases, it is possible to recognize the recrystallization of bone minerals (Lyman, 1994). The occurrence of calcium iron carbonates (ferro-dolomite), characterized by typically geopetal growth, indicates a deep diagenesis stage. These remains show substitution of biogenic apatite by the francolite variety in which $\mathrm{PO}_{4}{ }^{3-}$ is substituted by $\mathrm{CO}_{3}{ }^{2-}$ and $\mathrm{OH}^{-}$by $\mathrm{F}^{-}$(Elorza et al., 1999; Elliott, 2002). The presence of fluoride is, therefore, an indicator of diagenetic ion exchange through interaction with ground water (Hollocher et al., 2005). This type of replacement is not observed in the theropod bone from the fluvial channel.

The theropod bone transported by the fluvial channel-lag displays well-preserved bone microstructure. However, it experienced intense abrasion and selection by hydraulic transport. The bone shows vascular canals, secondary osteons and cancellous spaces cemented by iron oxides, siderite and calcite. In the perimedullary region, a pre-burial fracture reveals two cementation episodes of calcite and semi-isotropic zeolite. Furthermore, the bone shows non-cemented fractures showing a pattern of iron oxide alteration on the rim produced by the contact with air. These "open" fractures, indicating post-fossilization weathering processes -subaerial exposure- flaking and fracturing, occurred during exhumation events.

In summary, during the burial history (Fig. 8), the saurischian bones went through compression processes as a result of lithostatic pressure, permineralization and fracturing. Initially, iron oxide coatings and clay/ silt sediments were deposited in vascular canals and cancellous spaces. Later in time, lithostatic pressure caused a series of plastic deformations in bones after losing their collagen fibers. In bone voids and preburial fractures, a series of permineralization events of different minerals took place. The final exhumation processes are evident throughout post-fossilization weathering, flaking and fracturing that occurred during the telodiagenesis. These processes are the result of differences in burial depth, temperature and geostatic pressure suffered by the fossils in each burial environment. Similar diagenetic features have been identified in other vertebrate remains (Holz and Schultz, 1998; Wings, 2004; Reichel et al., 2005; González Riga and Astini, 2007; González Riga et al., 2009; Casal et al., 2013; Previtera, 2011, 2013; Previtera et al., 2013; Previtera et al., 2016).

\section{Conclusions}

In this paper, a bone histology and a diagenetic analysis of saurischian remains from the Neuquén Group have been achieved. Histological examination of these subadult/adult individuals reveals a predominance of fibrolamellar bone tissue suggesting a rapid periosteal osteogenesis and an overall fast growth. However, the existence of growth rings in the theropod bone indicates periodic interruptions of growth, probably related to environmental stress and a flexible growth strategy.

From a fossil-diagenetic viewpoint, dinosaur remains found in floodplain facies and fluvial channel, show similar events of permineralization and compaction. However, slight differences in the types of cements precipitated and in the number of diagenetic events that occurred during the burial history have been recognized. During the exposition on the ground, the sauropod carcasses were likely affected by subaerial decay, weathering and entombment. In contrast, theropod bones were transported by hydraulic currents suffering intense processes of selection and abrasion. The diagenetic processes 


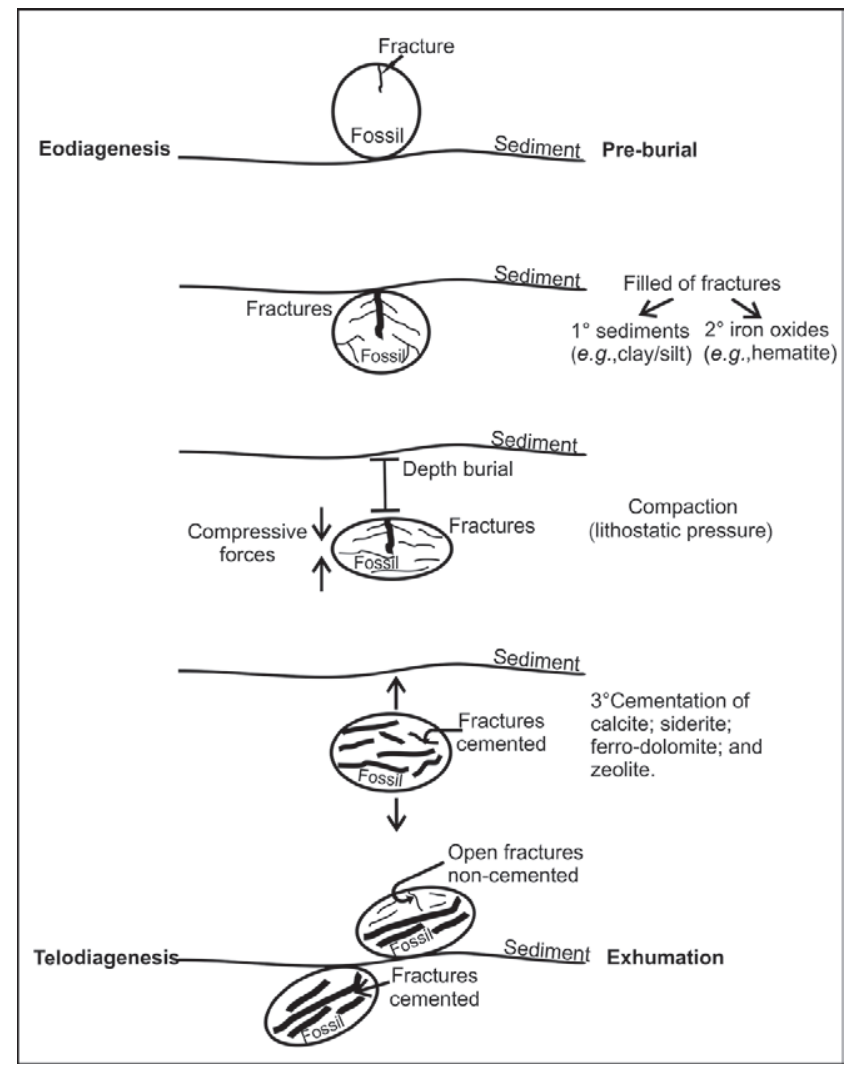

FIG. 8. Schematic diagram summarizing general taphonomic processes observed in dinosaur fossils in the burial environments.

observed comprise substitution, fracturing, plastic deformation and permineralization events. XRD and petrographic analysis confirm the substitution of hydroxyapatite by francolite in the bone microstructure. The content of fluorine found in the sauropod femur was not detected in the theropod long bone, which confirmed the differences between the two samples and their depositional environments: floodplain and fluvial channel respectively. During early stages of diagenesis, bone voids and pre-burial fractures were filled by iron oxides, after which precipitation of calcite and iron carbonates took place. In both fluvial channel and floodplain facies, the dominant authigenic mineral is hematite and the main cement of bone voids is calcite. The occurrence of geopetal structures, typical of ferro-dolomite, indicates a deep diagenesis stage and provides useful information about taphonomic processes of reburial. The final exhumation processes are evident throughout postfossilization weathering, flaking and fracturing that occurred during the telodiagenesis. These processes are the result of differences in burial depth, temperature and geostatic pressure suffered by the fossils in each burial environment. The functional use of XRD and petrographic analysis provided a fundamental tool that enabled a better understanding of the diagenetic pathways and differential preservation of dinosaur bones in fluvial environments.

\section{Acknowledgments}

This paper evolved from discussions of various taphonomic and environmental aspects of the author's doctoral dissertation at the Universidad Nacional de Córdoba, Argentina. I thank B. González Riga and $\mathrm{R}$. Astini for directing the paleontological works that made this manuscript possible. The petrographic microscope used for histological and diagenetic analysis was provided by the Facultad de Ciencias Exactas, Físicas y Naturales (Universidad Nacional de Córdoba-CONICET). The IANIGLA-CCT-Mendoza provided assistance during fieldworks. I gratefully acknowledge M. Reichel and R. Coria reviewers for their constructive and valuable 
comments which improved the manuscript. I especially thank M. Bourguet and C. Sancho for their valuable support in the fieldworks. I am particularly grateful to A. Mancuso for her constructive comments and L. Starkman for improving the English version. This research was supported by the following projects PICT BID 2005/33984 to J. Calvo; PIP CONICET 5222 to W. Volkheimer and PIP 0713/09 to B. González Riga.

\section{References}

Alcalá Martínez, L.1994. Macromamíferos neógenos de la fosa de Alfambra-Teruel. Departamento de Paleontología de la Facultad de Ciencias Geológicas de la Universidad Complutense de Madrid. Instituto de Estudios Turolenses y Museo de Ciencias Naturales: 554 p. Teruel, España.

Amprino, R. 1947. La structure du tissu osseux envisagée comme l'expression de différences dans la vitesse de l'accroissement. Archives de Biologie 58: 315-330.

Andreis, R.R.; Iñíguez Rodríguez, A.M.; Lluch, J.J.; Sabio, D.A. 1974. Estudio sedimentológico de las formaciones del Cretácico Superior del área del Lago Pellegrini, Provincia de Río Negro, República Argentina. Revista de la Asociación Geológica Argentina 29: 85-104.

Apesteguía, S. 2004. Bonitasaura salgadoi gen. et sp. nov.: a beaked sauropod from the Late Cretaceous of Patagonia. Naturwissenschaften 91: 493-497.

Behrensmeyer, A.K.1978. Taphonomic and ecologic information from bone weathering. Paleobiology 4: 150-162.

Behrensmeyer, A.K.; Willis, B.J.; Quade, J. 1995. Floodplains and paleosols of Pakistan Neogene and Wyoming Paleogene deposits: a comparative study. Palaeogeography, Palaeoclimatology, Palaeoecology 115: 37-60.

Bonaparte, J.F. 1991. The Gondwanan theropod families Abelisauridae and Noasauridae. Historical Biology 5:1-25.

Bonaparte, J.F.; Coria, R.A.1993. Un nuevo y gigantesco saurópodo Titanosaurio de la Formación Río Limay (Albiano-Cenomaniano) de la provincia del Neuquén, Argentina. Ameghiniana 30: 271-282.

Botha-Brink, J.; Smith, R.M.H. 2011. Osteohistology of the Triassic archosauromorphs Prolacerta, Proterosuchus, Euparkeria and Erythrosuchus from the Karoo Basin of South Africa. Journal of Vertebrate Paleontology 31: 1238-1254.

Bridge, J.S. 2003. Rivers and floodplains. Blackwell Publishing: 608 p. Oxford.

Burley, S.; Kantorowicz, J.Y.; Waugh, B. 1985. Clastic diagenesis. In Sedimentology recent developments and applied aspects (Brenchley, P.; Williams, B.; editors). Blackwell: 189-226. Oxford.

Calvo, J.O.; González Riga, B.J. 2003. Rinconsaurus caudamirus gen. et sp. nov., a new titanosaurid (Dinosauria, Sauropoda) from the Late Cretaceous of Patagonia, Argentina. Revista Geológica de Chile 30 (2): 333-353. doi: 10.5027/andgeoV30n2-a11.

Calvo, J.O.; Porfiri, J.D.; Veralli, C.; Novas, F.E.; Poblete, F. 2004. Phylogenetic status of Megaraptor namunhuaiquii Novas based on a new specimen from Neuquén, Patagonia, Argentina. Ameghiniana 41 (4): 565-575.

Calvo, J.O.; Porfiri, J.D.; González Riga, B.J.; Kellner, A. 2007. A new Cretaceous terrestrial ecosystem from Gondwana with the description of a new sauropod dinosaur. Anais da Academia Brasileira de Ciencias 79: 529-541.

Casadío, S.A.1994. Estratigrafía y Paleontología del intervalo Maastrichtiano-Daniano en el occidente de la Provincia de La Pampa, Argentina. Ph.D. Thesis (Unpublished), Universidad Nacional de Córdoba: 420 p.

Casal, G.A.; Martínez, R.D.; Ibiricu, L.M.; González Riga, B.; Foix, N. 2013. Tafonomía del dinosaurio terópodo Aniksosaurus darwini, Formación Bajo Barreal, Cretácico Tardío de Patagonia, Argentina. Ameghiniana 50 (6): 571-592.

Chiappe, L.M.; Schmitt, J.G.; Jackson, F.D.; Garrido, A.; Dingus, L.; Grellet-Tinner, G. 2004. Nest Structure for Sauropods: Sedimentary Criteria for Recognition of Dinosaur Nesting Traces. Palaios 19 (1): 89-95.

Chinsamy, A. 1990. Physiologic implications of the bone histology of Syntarsus rhodesiensis (Saurischia: Theropoda). Palaeontologia Africana 27: 77-82.

Chinsamy, A. 1993. Bone Histology and growth trajectory of the prosauropod dinosaur Massospondylus carinatus Owen. Modern Geology 18: 319-329.

Chinsamy, A. 1997. Assessing the biology of fossil vertebrates through bone histology. Palaeontologia Africana 33: 29-35.

Chinsamy, A. 2005. The microstructure of dinosaur bone. The Johns Hopkins University Press: 194 p. Baltimore and London.

Chinsamy, A.; Raath, M.A.1992. Preparation of fossil bone for histological examination. Palaeontologia Africana 29: 39-44.

Clarke, J.B. 2004. A mineralogical method to determinate cyclicity in the taphonomic and diagenetic history of fossilized bones. Lethaia 37: 281-284.

Cohen, K.M.; Finney, S.C.; Gibbard, P.L.; Fan, J. 2013. The ICS International Chronostratigraphic Chart. Episodes 36 (3): 199-204. 
Coria, R.A.; Salgado, L. 1995. A new giant carnivorous dinosaur from the Cretaceous of Patagonia. Nature 377: 224-226.

Coria, R.A.; Currie, P.J. 2006. A new carcharodontosaurid (Dinosauria, Theropoda) from the Upper Cretaceous of Argentina. Geodiversitas 28: 71-118.

Curry, K.A. 1999. Ontogenetic histology of Apatosaurus (Dinosauria: Sauropoda) new insights on growth rates and longevity. Journal of Vertebrate Paleontology 19: 654-665.

Curry, K.A. 2005. Titanosauria. In The Sauropods, evolution and paleobiology (Curry Rogers, K.A.; Wilson, J.A.; editors). University of California Press: 50-103. Berkeley.

De Buffrénnil,V. 1980. Mise en evidence de l'incidence des conditions de milieu sur la croissance de Crocodylus siamensis (Schneider, 1801) et valeur des marques de croissance squelettiques pour l'evaluation de l'age individual. Archives de Zoologie Experimentale Generale 121: 63-76.

De Ricqlès, A. 1972. Recherches paléohistologiques sur les os longs desTétrapodes. Part III, Titanosuchiens, Dinocéphales et Dicynodontes. Annales de Paléontologie Vertébrés 58: 17-60.

De Ricqlès, A. 1976. On bone histology of fossil and living reptiles, with comments on its functional and evolutionary significance. In Morphology and biology of Reptiles (Bellairs, A.; Cox, B.; editors). Linnean Society of London and Academic Press: 126-150. London.

De Ricqlès, A.; Padian, K.; Horner, J.R. 2003. On the bone histology of some Triassic pseudosuchian archosaurs and related taxa. Annales de Paléontologie 89: 67-101.

Digregorio, J.H.; Uliana, M.A. 1980. Cuenca Neuquina. In Geología Regional Argentina (Turner, J.C.M.; editor). Academia Nacional de Ciencias 2: 985-1032. Córdoba.

Downing, K.F.; Park, L.E. 1998. Geochemistry and early diagenesis of mammal-bearing concretions from the Sucker Creek Formation (Miocene) of southeastern Oregon. Palaios 13: 14-27.

Elorza, J.; Astibia, H.; Murelaga, X.; Pereda-Suberbiola, X. 1999. Francolite as a diagenetic mineral in dinosaur and other Upper Cretaceous reptile bones (Laño, Iberian Peninsula): microstructural, petrological and geochemical features. Cretaceous Research 20: 169187. doi:10.1006/cres.1999.0144.

Elliott, J.C. 2002. Calcium phosphate biominerals. In Phosphates-Geochemical, Geobiological and Materials Importance (Kohn, M.J.; Rakovan, J.; Huges, J.M.; editors). Mineralogical Society of America, Reviews in Mineralogy 48: 427-453.
Fernández López, S.R.; Fernández Jalvo, Y. 2002. The limit between biostratinomy and fossildiagenesis. In Current Topics on Taphonomy and Fossilization (De Renzi, M.; Pardo Alonso, M.V.; Belinchón, M.; Peñalver, E; Montoya, P.; Márquez-Aliaga, A.; editors). Ajuntament of Valencia: 27-37. España.

Flügel, E. 1982. Microfacies Analysis of Limestones. Springer: 633 p. Berlin.

Francillon-Vieillot, H.; De Buffrenil, V.; Castanet, J.; Geraudie, J.; Meunier, F.J.; Sire, J.Y.; Zylberberg, L.; De Ricqles, A. 1990. Microstructure and mineralization of vertebrate skeletal tissues. In Skeletal biomineralization: patterns, processes and evolutionary trends (Carter, J.G.; editor). Van Nostrand Reinhold 1: 471-530. Nueva York.

Franzese, J.; Spalletti, L.; Gómez Pérez, J.; Macdonald, D. 2003. Tectonic and paleoenvironmental evolution of Mesozoic sedimentary basins along Andean foothills of Argentina ( $\left.32^{\circ}-54^{\circ} \mathrm{S}\right)$. Journal of South American Earth Sciences 16: 81-90.

Gallina, P.A. 2012. Histología ósea del titanosaurio Bonitasaura salgadoi (Dinosauria: Sauropoda) del Cretácico Superior de Patagonia. Ameghiniana 49 (3): 289-302.

Garrido, A.C.; Chiappe, L.M.; Jackson, F.; Schmitt, J.; Dingus, L. 2001. First sauropod nest structures. Journal of Vertebrate Paleontology 21 (3): 53A.

González Riga, B.J. 1999. Hallazgo de vertebrados fósiles en la Formación Loncoche, Cretácico Superior de la provincia de Mendoza, Argentina. Ameghiniana 36: 401-410.

González Riga, B.J. 2002. Estratigrafía y Dinosaurios del Cretácico Tardío en el extremo sur de la provincia de Mendoza, Argentina. Ph.D. Thesis (Unpublished), Universidad Nacional de Córdoba: 280 p. Argentina.

González Riga, B.J. 2003. A new titanosaur (Dinosauria, Sauropoda) from the Upper Cretaceous of Mendoza Province, Argentina. Ameghiniana 40: 155-172.

González Riga, B.J.; Curry Rogers, K.A. 2006. Osteohistology of the titanosaur Mendozasaurus (Dinosauria, Sauropoda): preliminary interpretations. In Congreso Argentino de Paleontología y Bioestratigrafía, No. 9, Resúmenes: 84 p. Córdoba.

González Riga, B.J.; Astini, R.A. 2007. Preservation of large titanosaur sauropods in overbank fluvial facies: A case study in the Cretaceous of Argentina. Journal of South American Earth Sciences 23: 290-303.

González Riga, B.J.; Calvo, J.O.; Porfiri, J. 2008. An articulated titanosaur from Patagonia (Argentina): new evidences of the pedal evolution. Palaeoworld 17: 33-40. 
González Riga, B.J.; Previtera, E.; Pirrone, C.A. 2009. Malarguesaurus florenciae gen. et sp. nov., a new titanosauriform (Dinosauria, Sauropoda) from the Upper Cretaceous of Mendoza, Argentina. Cretaceous Research 30: 135-148.

González Riga, B.J.; Lamanna, M.C.; Ortiz David, L.D.; Calvo, J.O.; Coria, J.P. 2016. A gigantic new dinosaur from Argentina and the evolution of the sauropod hind foot. Scientific Reports 6: 1-15.

Holz, M.; Schultz, C.L. 1998.Taphonomy of the south Brazilian triassic herpetofauna: fossilization mode and implications for morphological studies. Lethaia 31: $1-12$.

Hollocher, K.T.; Alcober, R.A.; Colombi, C.E.; Hollocher, T.C. 2005. Carnivore Coprolites from the Upper Triassic Ischigualasto Formation, Argentina: Chemistry, Mineralogy and Evidence for Rapid Initial Mineralization. Palaios 20: 51-63.

Horner, J.R.; De Ricqlès, A.; Padian, K. 1999. Variation in dinosaur skeletochronology indicators: Implications for age assessment and physiology. Paleobiology 25 (3): 295-304.

Howell, J.A.; Schwarz, E.; Spalletti, L.A.;Veiga, G.D. 2005. The Neuquén Basin: an overview. In The Neuquén Basin, Argentina: A Case Study in Sequence Stratigraphy and Basin Dynamics (Veiga, G.; Spalletti, L.; Howell, J.; Schwarz, E.; editors). Geological Society of London, Special Publications 252 (1): 1-14.

Ibiricu, L.M.; Martínez, R.D.; Casal, G.A.; Cerda, I.A. 2013. The behavioral implications of a multi-individual bonebed of a small theropod dinosaurs. Plos One 8 (5): e64253. doi: 10.1371-journal.pone.0064253.

Klein, N.; Sander, M. 2008. Ontogenetic stages in the long bone histology of sauropod dinosaurs. Paleobiology 34 (2): 247-263.

Leanza, H.A.; Hugo, C.A. 2001. Cretaceous red beds from southern Neuquén Basin, Argentina: age, distribution and stratigraphic discontinuities. In Asociación Paleontológica Argentina (Leanza, H.A.; editor). International Simposium on Mesozoic Terrestrial Ecosystem, No. 7, Publicación especial 7: 117-122. Buenos Aires.

Leanza, H.A.; Apesteguia, S.; Novas, F.; de La Fuente, M.S. 2004. Cretaceous terrestrial beds from the Neuquén Basin, Argentina and their tetrapod assemblages. Cretaceous Research 25: 61-87.

Legarreta, L.; Uliana, M.A. 1991. Jurassic-Cretaceous marine oscillations and geometry of back-arc basin fill, central Argentine Andes. In Sedimentation, Tectonics and Eustasy: Sea level Changes at Active
Plate Margins (MacDonald, D.I.; editor). International Association of Sedimentologists, Special Publication 12: 429-450. Oxford.

Legarreta, L.; Kokogian, D.A.; Boggetti, D.A. 1989. Depositional sequences of de Malargüe Group (Upper Cretaceous-Lower Tertiary), Neuquén Basin, Argentina. Cretaceous Research 10: 337-356.

Lim, D.I.; Jung, H.S.; Yang, S.Y.; Yoo, H.S. 2004. Sequential growth of early diagenetic freshwater siderites in the Holocene coastal deposits, Korea. Sedimentary Geology 169: 107-120.

Lucas, J.; Prévôt, L.E. 1991. Phosphates and Fossil Preservation. In Taphonomy: Releasing the Data Locked in the Fossil Record (Allison, P.A.; Briggs, D.E.G.; editors). Plenum Press: 389-409. New York.

Lyman, R.L. 1994. Vertebrate Taphonomy. Cambridge University Press: 524 p. Cambridge.

Madsen, J.H. 1976. Allosaurus fragilis: a revised osteology. Bulletin of the Utah Geological and Mineral Survey 109: 1-163.

Marshall, L.G. 1989. Bone modification and "the laws of burial.” In Bone modification (Bonnichsen, R.; Sorg, M.H.; editors). University of Maine Center for the Study of the First Americans 7-24. Orono.

Martinsen, O.J.; Ryseth, A.; Helland-Hansen, W.; Flesche, H.; Torkildsen, G.; Idil, S. 1999. Stratigraphic base level and fluvial architecture: Ericson Sandstone (Campanian), Rock Springs Uplift, SW Wyoming, U.S.A. Sedimentology 46: 235-259.

Miall, A.D. 1996. The Geology of Fluvial Deposits. Springer-Verlag Berlin Heidelberg: 583 p. New York.

Mortimer, R.J.G.; Coleman, M.L.; Rae, J.E. 1997. Effect of bacteria on the elemental composition of early diagenetic siderite; implications for palaeoenvironmental interpretations. Sedimentology 44: 759-765.

Novas, F.E. 1996. Alvarezsauridae, Cretaceous basal birds from Patagonia and Mongolia. Memoirs of the Queensland Museum 39: 675-702.

Novas, F.E. 1997. Megaraptor namunhuaiquii, gen. et sp. nov., a large clawed Late Cretaceous theropod from Patagonia. Journal of Vertebrate Paleontology 18: 4-9.

Novas, F.E.; Puerta, P. 1997. New evidence concerning avian origins from the Late Cretaceous of Patagonia. Nature 387: 390-392.

Paik, I.S.; Kim, H.J.; Park, K.H.; Song, Y.S.; Lee, Y.I.; Hwang, J.Y.; Huh, M. 2001. Paleoenvironments and taphonomic preservation of dinosaur bone-bearing deposits in the Lower Cretaceous Hasandong Formation, Korea. Cretaceous Research 22: 627-642. 
Parras, A.M.; Casadío S.; Pires, M. 1996. Secuencias depositacionales del Grupo Malargüe y el límite Cretácico-Paléogeno, en el sur de la provincia de Mendoza, Argentina. Asociación Paleontológica Argentina, Publicación Especial 5: 61-69.

Parras, A.; De La Mata, I.; González Riga, B.J.; Previtera, E. 2001. Arroyo Calmu-Co, nueva localidad con fauna de invertebrados y vertebrados del CampanianoMaastrichtiano de la provincia de Mendoza, Argentina. In Reunión Anual de Comunicaciones de la Asociación Paleontológica Argentina. Ameghiniana 38 (4): 39R. Buenos Aires.

Pate, F.D.; Hutton, J.T.; Norrish, K.1989. Ionic exchange between soil solution and bone: Toward a predictive model. Applied Geochemistry 4: 303-316.

Piepenbrink, H. 1989. Examples of chemical changes during fossilization. Applied Geochemistry 4: 273-280.

Powell, J.E. 2003. Revision of South American Titanosaurid dinosaurs: palaeobiological, palaeobiogeographical and phylogenetic aspects. Records of the Queen Victoria Museum: 173 p. Launceston.

Previtera, E. 2005. Vertebrados fósiles y paleoambientes cretácicos de La Formación Loncoche en Calmu-Co, provincia de Mendoza, Argentina. Licenciate Thesis (Unpublished), Universidad del Aconcagua, Argentina: 97 p. Mendoza.

Previtera, E. 2011. Tafonomía de Dinosaurios Cretácicos de la Cuenca Neuquina sur mendocina, Patagonia Argentina. Ph.D. Thesis (Unpublished), Universidad Nacional de Córdoba: 202 p.

Previtera, E. 2013. Tafonomía de vertebrados del Cretácico Superior de la Formación Loncoche en Calmuco (Mendoza, Argentina): implicancias paleoambientales y paleogeográficas. Ameghiniana 50: 483-492.

Previtera, E.; González Riga, B.J. 2008. Vertebrados cretácicos de la Formación Loncoche en Calmu-Co, Mendoza, Argentina. Ameghiniana 45 (2): 349-359.

Previtera, E.; D'angelo, J.A.; Mancuso, A.C. 2013. Preliminary chemometric study of bone diagenesis in Early Triassic cynodonts from Mendoza, Argentina. Ameghiniana 50: 460-468.

Previtera, E.; Mancuso, A.C.; De La Fuente, M.S.; Sánchez, E.S. 2016. Diagenetic analysis of tetrapod from the Upper Triassic, Puesto Viejo Group, Argentina. Andean Geology 43 (2): 197-214. doi: 10.5027/ andgeoV43n2-a03.

Ramos, V. 1981. Descripción geológica de la Hoja 33c, Los Chihuidos Norte, Provincia de Neuquén. Servicio Geológico Nacional, Boletín 182: 103 p. Buenos Aires.
Reichel, M.; Schultz, C.L.; Pereira, V.P. 2005. Diagenetic pattern of vertebrate fossils from the Traversodontidae Biozone, Santa María Formation (Triassic), Southern Brazil. Revista Brasileira de Paleontología 8 (3): 173-180.

Reid, R.E.H.1990. Zonal growth rings in dinosaurs. Modern Geology 15: 19-48.

Reid, R.E.H. 1996. Bone histology of the ClevelandLloyd dinosaurs and of the dinosaurs in general, part 1: introduction to bone tissues. Brigham Young Universtiy Geology Studies 41: 25-71.

Retallack, G.J. 2001. Soils of the Past. An introduction to Paleopedology. Blackwell Science: 404 p. Oxford.

Rogers, R.R.; Fricke, H.C.; Addona,V.; Canavan, R.R.; Dwyer, C.N.; Harwood, C.L.; Koenig, A.E.; Murray, R.; Thole, J.T.; Williams, J. 2010. Using laser ablationinductively coupled plasma-mass spectrometry (LA-ICP-MS) to explore geochemical taphonomy of vertebrate fossils in the Upper Cretaceous Two Medicine and Judith River formations of Montana. Palaios 25: 183-195.

Salgado, L.; Bonaparte, J.F. 1991. Un nuevo saurópodo Dicraeosauridae, Amargasaurus cazaui gen. et sp. nov., de la Formación La Amarga, Neocomiano de la provincia de Neuquén, Argentina. Ameghiniana 28: 333-346.

Salgado, L.; Coria, R.A.; Calvo, J.O. 1997. Evolution of Titanosaurid Sauropods. I: Phylogenetic analysis based on the postcraneal evidence. Ameghiniana 34: 3-32.

Sander, P.M. 2000. Longbone histology of the Tendaguru sauropods: implications for growth and biology. Paleobiology 26: 466-488.

Scasso, R.A.; Limarino, C.O. 1997. Petrología y diagénesis de rocas clásticas. Asociación Argentina de Sedimentología, Publicación Especial 1: 259 p.

Schmidt, V.; Mcdonald, P.A. 1979. The role of secondary porosity in the course of sandstone diagenesis. In Aspects of diagenesis (Scholle, P.A.; Schluger, P.R.; editors). Special Publication Society for Sedimentary Geology 26: 175-207. Tulsa.

Schwarz, E. 2012. Sharp-based marine sandstone bodies in the Mulichinco Formation (Lower Cretaceous), Neuquén Basin, Argentina: remnants of transgressive offshore sand ridges. Sedimentology 59: 1478-1508.

Sereno, P.C.; Martínez, R.N.; Wilson, J.A.; Varricchio, D.J.; Alcober, O.A.; Larsson, H.C. 2008. Evidence for avian intrathoracic air sacs in a new predatory dinosaur from Argentina. Plos One 3 (9): e3303. doi:10.1371/journal.pone.0003303. 
Smith, R.M.1993. Vertebrate Taphonomy of Late Permian floodplain deposits in the Southwestern Karoo Basin of South Africa. Palaios 8: 45-67.

Smith-Gill, J.S.1983. Developmental plasticity: developmental conversion versus developmental modulation. American Zoologist 23: 47-55.

Starck, J.M.; Chinsamy, A. 2002. Bone microstructure and developmental plasticity in birds and other dinosaurs. Journal of Morphology 254: 232-246.

Trueman, C.N.G.; Behrensmeyer, A.K.; Tuross, N.; Weiner, S. 2004. Mineralogical and compositional changes in bones exposed on soil surfaces in Ambosely National Park, Kenya: diagenetic mechanism and the role of sediment pore fluids. Journal of Archaeological Science 31: 721-739.

Tucker, M.E. 1991. The diagenesis of fossils. In The processes of fossilization (Donovan, S.K.; editor). Columbia University Press: 84-104. New York.
Varricchio, D.J. 1993. Bone microstructure of the Upper Cretaceous theropod dinosaur Troodon formosus. Journal of Vertebrate Paleontology 13: 99-104.

Williams, C.T.; Marlow, C.A. 1987. Uranium and Thorium distributions in fossil bones from Olduvai Gorge, Tanzania and Kanam, Kenya. Journal of Archaeological Science 14: 297-309.

Wilson, J.A. 2002. Sauropod dinosaur phylogeny: critique and cladistic analysis. Zoological Journal of the Linnean Society 136: 217-276.

Wilson, J.A.; Martínez, R.N.; Alcober, O. 1999. Distal tail segment of a Titanosaur (Dinosauria: Sauro-poda) from the Upper Cretaceous of Mendoza, Argentina. Journal of Vertebrate Paleontology 19: 591-594.

Wings, O. 2004. Authigenic minerals in fossil bones from the Mesozoic of England: poor correlation with depositional environments. Palaeogeography, Palaeoclimatology, Palaeoecology 204: 15-32. 